\title{
Carcinoma of the Eyelid pT4 TNM Finding v7
}

National Cancer Institute

\section{Source}

National Cancer Institute. Carcinoma of the Eyelid pT4 TNM Finding v7. NCI Thesaurus. Code C88568.

Unresectable carcinoma of the eyelid due to extensive invasion of ocular, orbital, and craniofacial structures, or brain. (from AJCC 7th Ed.) 